
My current work is focused on China. Most Chinese CEOs are averse to the management practices of Valve, Oticon, and similar companies, but at the same time they admire Jack Ma at Alibaba and similar management mavericks. What they have not yet understood is that Jack Ma and other successful Chinese managers run their companies in a way that looks more like Valve than conventional Chinese management. The day they learn it, Western companies will have a hard time competing.

\section{LARS KOLIND}

Author and consultant

Copenhagen, Denmark

E-mail: lars@kolind.dk 